\title{
Ciddi Yanıklı Hastanın Acil Dönemdeki Bakımı*
}

\author{
The Care of Patient with Major Burn in the Emergency Period
}

\author{
Didem ÖZTÜRK ${ }^{* *}$, Neriman AKYOLCU ${ }^{* * *}$
}

İletişim/Correspondence: Didem ÖZTÜRK Adres/Address: İstanbul Üniversitesi Florence Nightingale Hemşirelik Fakültesi, Cerrahi Hastalıkları Hemşireliği AD., Abide-i Hürriyet Cad. 34381, Şişli/İstanbul Tel: 0212440 0000/27042 Fax: 02122244990

E-mail: didem_ztrk@hotmail.com

\section{$\ddot{O} Z$}

Yanıklar, nekroz ve sistemik hasarların geliştiği, insanların acı çekmesine, sakat kalmasına ve ölmesine neden olan, ülke ekonomisine ciddi yükler getiren önemli travmalardan biridir. Acil dönem, yanığın oluşması ile birlikte sıvı kaybı ve ödem gelişimini izleyen, sivı tedavisinin tamamlanmasına ve diürezin başlamasına kadar devam eden, yaklaşık 2448 saat süren dönemdir. Bu dönemde doğru, eksiksiz, hızl tanılama yapılarak, yaşam kurtarıcı acil girimlerin hemen başlatılması gerekmektedir. Uygulanacak bakım girişsimleri havayolu açıklı̆̆ını, solunumu, dolaşımı sağlama ve sürdürme, sıvı tedavisi, yara bakımı ve beslenme desteğine temellenir. Yanıklı hastaya bakım veren hemşire, yanık sonrası oluşan fizyolojik değişikliklere iliş̧kin güncel ve kapsamlı bilgiye ve hastanın durumundaki ani değişiklikleri fark edebilecek kritik değerlendirme becerisine sahip olmalıdır. Ayrıca hemşire, yaşam riskinin yanında ciddi travma nedeniyle psikososyal sorun yaşayan hasta ve ailesine duyarl, nazik ve şefkatli bir tutum içinde, gereksinimleri temelinde bakım sağlayabilmelidir.

Anahtar Kelimeler: Acil servis, hemşirelik bakımı, yanıklar.

\section{ABSTRACT}

Burns are one of the important traumas which cause to necrosis and systemic damages, to lead people to suffer, to become disabled and even to death, and to bring severe burdens on the country's economy. The emergency period is the time of about 24-48 hours that begins with the formation of burn, followed by loss of fluid and developing of oedema, continues until completing the treatment of fluid and beginning the diuresis. Within this period, the life-saving emergency interventions are required to be started immediately by performing an accurate, complete and rapid diagnosis. Care interventions to be applied are based on ensuring and sustaining the intact airway passage, respiration and circulation, fluid-electrolyte balance and wound care as well as on nutritional support. The nurse who provides care to the patient with burn should have the actual and comprehensive knowledge regarding the physiological changes occurred post-burn period and the skill of critical evaluation to realize the sudden changes in the patient's condition. In addition to this, the nurse should be able to provide care to the patient who experiences psychosocial problem due to trauma besides the risk of life and their family, in a sensitive, gentle and caring attitude, based on their requirements.

Keywords: Emergency service, nursing care, burns.

*2. Ulusal Acil Hemşireliği Kongresi'nde poster bildiri olarak sunulmuştur (19-21 Nisan 2013, Kuşadast), **Arş. Gör. İstanbul Üniversitesi Florence Nightingale Hemşirelik Fakültesi, ***Prof. Dr. İstanbul Üniversitesi Florence Nightingale Hemşirelik Fakültesi

Yazının gönderilme tarihi: 03.03.2015

Yazının basım için kabul tarihi: 04.12.2015 


\section{GİRIŞ}

Vücudun dış ortamla ilişkisini sağlayan cildin sıcaklık, kimyasal maddeler, radyasyon ya da elektrik ak1mı sonucu bütünlüğünün bozulmasıyla oluşan, bireyi fiziksel ve psikolojik açıdan etkileyen yanıklar, nekroz ve sistemik hasarların gelişmesine, bireylerin acı çekmesine, sakat kalmasına ve ölmesine neden olabilen, ülke ekonomisine ciddi yükler getiren önemli travmalardan biridir (Appleby 2005; Burke, Mohn-Brown ve Eby 2011; Nair 2009; Niggemeyer ve Thurman 2012). Tüm dünyada sıklıkla rastlanan yanık yaralanmalar1, öncelikle fiziksel ve psikolojik sağlıktan sapmaları beraberinde getirerek birey ve ailenin yaşam biçimini olumsuz yönde etkileyen, toplumsal ve ekonomik boyutu olan önemli bir sağlık sorunudur (Kanan 2012; Nair 2009).

Amerikan Yanık Birliği'nin (American Burn Association-ABA) 2013 yılı verilerine göre; yaklaşık 450.000 yanıklı hastanın hastaneye başvurduğu, 30.000'i yanık merkezinde olmak üzere 40.000'inin hastanede yatarak tedavi gördügü ve 3.400'ünün yaşamını yitirdiği belirtilmiştir (ABA 2013). Türkiye'de 2004 yılı Sağlık İstatistikleri'ne göre 7678 yanık yaralanmasının hastanede tedavi edildiği ve 173 'ünün yaşamını kaybettiği bildirilmiştir (Kurşun ve Kanan 2011).

Iqbal, Saaiq ve Ali (2013)'nin 13295 yanıklı hasta üzerinde gerçekleştirdikleri çalışmada; tüm yaşlarda erkek ve kadın gruplarında haşlanma yanığının (\%42.48) ilk sirada yer aldığı; bunu alev yanığı (\%39) ve elektrik yanıklarının (\%9.96) izlediği; inhalasyon yaralanmasının ise oldukça düşük (\%1.12) olduğu gözlenmiştir. Yine aynı çalışmada hastanede kalış süresi ortalama $12.16 \pm 6.07$ gün (2-73 gün); genel mortalite oranı ise \%1.48 olarak görülmüştür.

Yanı̆̆1 olan hastanın tedavi ve bakımı, yaralanma süresi ve ciddiyetine bağlı olarak değişir. Yanığın ciddiyeti; (1) yanığın derinliği, (2) TBYA yüzdesi ile hesaplanmış yanık genişliği, (3) yanığın yeri ve (4) hastaya ilişkin risk faktörleriyle belirlenir (Kanan 2012). ABA (2006)'ya göre, TBYA \%25'ten daha fazla derin k1smi kalınlıklı yanıklar, TBYA \%10'dan daha fazla tam kalınlıklı yanıklar, yüz, gözler, kulaklar, eller, ayaklar ya da perineden birini içeren yanıklar; elektrik yanıkları, inhalasyon yaralanmaları, başka yaralanmaların (kırık vb.) eşlik ettiği yanıklar; kronik kalp, akciğer ya da endokrin hastalığı olan hastalar ile 60 yaşın üstündeki hastalar ciddi yanıklı hastalar grubunu oluşturmaktadır (Coffee 2006; Mohn-Brown 2008; Regojo 2008).

Yanığın ciddiyetinin yanında vücutta oluşturduğu fizyopatolojik değişikliklerle doğrudan ilişkili bir diğer faktör yaralanma süresi temel alındığında, tedavi ve bakım girişimleri, acil, akut ve rehabilitasyon dönemlerini içeren üç evrede gerçekleştirilir. Bu evrelerin ilkini oluşturan acil dönem; yanığın oluşması ile birlikte sıvı kaybı ve ödem gelişimi ile başlayan, sıvı tedavisinin tamamlanmasına ve diürezin başlamasına kadar devam eden, yaklaşı 24-48 saatlik zamanı kapsar. Bu dönemde doğru, eksiksiz, hızlı tanılama yapılarak, yaşam kurtarıcı acil girişimlerin başlatılması gerekir (Burke ve ark. 2011; Kanan 2012; Regojo 2008).

Bu makale, ciddi yanıklı hastaların acil dönemdeki tedavi ve bakım girişimleri kapsamında değerlendirilmesi, yönetimi ve izleminde; acil serviste çalışan hemşirelere rehberlik edebilecek bakım girişimlerini literatür ışığında tartışmak amacıyla ele alındı.

\section{ACİL DÖNEM ORTAK BAKIM GİRIŞ̧IMLERİ}

Ortak bakım girişimleri, havayolu açıklığını, solunu$\mathrm{mu}$, dolaşımı ve sıv1-elektrolit dengesini sağlama ve sürdürme ile yara bakımı odaklıdır. Amaç, havayolu açıklığının sağlanması ve yanık şokunun önlenmesidir (Kanan 2012; Mohn-Brown 2008; Regojo 2008).

Yanık hastasında, yanığa ek başka yaralanmalar da olabilir; bu nedenle, hasta başlangıçta tanılamanın kolaylığ açısından “ABCD” şeklinde bir sıralama oluşturulmuştur. Birincil tanılama hava yolunun sağlanmas1 ve servikal vertebranın korunması (A), solunumun kontrolü (B), dolaşımın kontrolü (C), bilinç durumunun değerlendirilmesi (D) şeklindeki sırayla yapılır. Hava yolu açıklığı değerlendirilirken servikal omurga stabilize edilir. Yanık yaralanmaları daha sonra 
değerlendirilir (Niggemeyer ve Thurman 2012; Regojo 2008; Wraa 2003).

İlk değerlendirmeyi takiben baştan ayağa ikinci bir değerlendirme yapılmalıdır. Hastanın baştan ayağa değerlendirilmesi, potansiyel olarak yaşamı tehdit eden diğer yaralanmaların tanılanmasında önemlidir. Koşulların izin verdiği ölçüde öykü alınır, yaralanmanın nasıl ve ne zaman meydana geldiği, olayın olduğu yerin çevresel özellikleri öğrenilir (Çetinkale 2005; Niggemeyer ve Thurman 2012; Regojo 2008; Wraa 2003).

\section{Tanılayıcı Testleri}

Hastanın durumunu değerlendirmek ve gerekli girişimleri belirlemek amaciyla kullanılır.

- Idrar tetkiki; hastanın böbrek perfüzyonunun ve beslenme durumunun yeterliliğini gösterir. Katabolik evrede idrarla büyük miktarlarda azot atılır. Azot kayb1, 24 saatlik idrarda toplam azot, üre nitrojen ve aminoasit nitrojen miktarının ölçülmesiyle belirlenir. Koyu kahverengi, şarap renkli idrar gibi miyoglobinüri, akut tübüler nekroz gelişiminin göstergesidir. Proteinüri ve idrarın özgül ağırlığının artması, plazma protein kaybını ve dehidratasyonu düşündürür. Glukozüri, ciddi yanıklı hastalarda geçici bir gelişmedir; bu durum bir beslenme programının düzenlenmesinin gerekliliğini gösterir.

- Tam kan sayımı düzenli olarak izlenir. Hematokrit düzeyi, kan konsantrasyon düzeyinin artması ve intravasküler alandan sıvı geçişi durumunda ikincil olarak yükselir. Hemoglobin hemolize bağlı olarak azalır. İnfeksiyon varsa, lökosit düzeyi artar.

- Serum elektrolitleri düzenli olarak izlenir. Sodyum düzeyleri interstisyuma yoğun sıvı geçişi durumuna bağlı olarak azalır. Potasyum seviyesi, başlangıçta hücre lizisi ve hücre dışı boşluğa sıvı geçişinin bir sonucu olarak yanık şokunda yükselir.

- Böbrek fonksiyon test sonuçları yakından izlenir. Kan üre nitrojen (BUN) dehidratasyonda; kreatinin ise böbrek yetmezliğinde yükselir.

- Toplam protein, albumin, transferrin, prealbumin, retinol bağlayıcı protein, alfa-1 asit glikoprotein ve
C-reaktif protein ölçümü, protein sentezini ve beslenme durumunu gösterir.

- Kreatin fosfokinaz (CPK); elektrik yanığ1 sonrası geniş kas hasarına bağlı olarak yükselir. Kan glukoz düzeyi ciddi yanık sonrası geçici olarak yükselir.

- Arteriyel kan gazı (AKG); hipoksi ve asit-baz dengesizliğinin varlığına işaret eder ve oksijen tedavisinde değişikliklere hastanın yanıtları gösterilmektedir. Yanıklı hasta $\mathrm{pH}$ düzeyi yüksek ya da düşük olabilir. $\mathrm{PCO}_{2}$ ve $\mathrm{PO}_{2}$ düzeyi azalmış ve bikarbonat seviyesi normal ya da düşük olabilir.

- Pulse oksimetre ile oksijen satürasyon seviyeleri sürekli değerlendirilir. Yanıklı hastanın oksijen satürasyonu \%95'in altında olabilir.

- Akciğer grafisi; ilk 24 ile 48 saat içinde atelektazi, akciğer ödemi veya akut solunum sıkıntısı sendro$\mathrm{mu}$ (ARDS) vb. değişiklikleri yansitabilir.

- Elektrokardiyografi (EKG) ve kardiyak enzimler; elektrik yanıklı ya da kalp hastalığı öyküsü olan hastalarda kontrol edilmelidir (Burke ve ark. 2011; Eti-Aslan ve Oyur-Çelik 2014; Mohn-Brown 2008; Stout 2009).

\section{Ortak Bakım Girişimleri}

Hastanın durumunu ya da yanığın fizyopatolojik etkisini değerlendirmeye yönelik bu testler yapılırken, aynı zamanda başlatılan ortak bakım girişimleri kapsamında, havayolu açıklığını, solunumu ve dolaşımı sağlama ve sürdürme, sıvı tedavisi, yara bakımı, beslenme desteği ve destekleyici girişimler yer alır.

\section{Havayolu Açıklığının Sağlanması ve Sürdürülmesi}

Havayolu açıklığını sağlama ve sürdürmede havayoluna ilişkin ciddi komplikasyonlar oluşmadan önce nazotrakeal ya da endotrakeal entübasyon gerekliliğinin belirlenmesi önemlidir. Orofarenkste eritem, kabarcık veya ülserasyon belirti ve bulguları kontrol edilmeli ve hastanın entübasyona gereksinimi olabileceği düşünülmelidir Hastada huzursuzluğun artması, nefes darlığı, yutma güçlügü, ses kısıklığı, hızlı ve yüzeyel solunum izlenmelidir. Tam tıkanma gelişmeden önce erken entübasyon önerilir. Boyundaki ödem nedeniyle trakeostomi zor olacağından, başlangıçta trakeosto- 
miden kaçınılmalıdır (Carrougher ve Sandidge 2009; Niggemeyer ve Thurman 2012; Wraa 2003).

\section{Solunumun Sağlanması ve Sürdürülmesi}

Boyun ve gövdeyi çevreleyen tam kalınlıklı yanıklara bağlı solunum sıkıntısının azaltılmasında göğüs duvarına eskaratomi gerekebilir. Duman inhalasyonu olas1lığında, yanık sonrası 6 ile 12 saat içinde alt solunum yolunu değerlendirmek için fiberoptik bronkoskopi yapılır. Alt solunum yollarında karbonsu materyal görünümü, mukoza ödemi, kabarcıklar, eritem, kanama ve ülserasyon önemli bulgular arasındadır (Eti-Aslan ve Oyur-Çelik 2014; Kanan 2012; Niggemeyer ve Thurman 2012; Wraa 2003).

Acil servise başvuran hastanın solunum sisteminin değerlendirilmesine yönelik akciğer grafisi, AKG, yaşam bulguları ve karboksihemoglobin düzeyi vb. birkaç temel değerlendirme elde edilmelidir: Entübasyon gögüs, yüz veya boyun yanıklı tüm hastalar için endikedir. Tedavide amaç, atelektazinin önlenmesi ve alveoler oksijen alışverişinin sürdürülmesidir (Carrougher ve Sandidge 2009).

Havayolu açıklığı ile solunumu sağlama ve sürdürmeye yönelik aşağıdaki girişimler hemen başlatılmalıdır:

- Havayolunu açık tutmak için, hasta sık sık aspire edilmelidir.

- Hastanın solunumunu desteklemek amaciyla yatak başı $30^{\circ}$ yükseltilmelidir.

- Karbonmonoksit zehirlenmelerinde, karboksihemoglobin düzeyi normale dönene kadar $\% 100 \mathrm{O}_{2}$ verilmelidir.

- Havayolu tıkanıklığı durumunda, hasta acil entübe edilmelidir. Hasta tarafindan daha iyi tolere edildiği ve daha kolay tespit edildiği için nazotrakeal entübasyon uygulanır; ancak burun ve dudak çevresinde (nazolabial) yanıklar varsa bu durumda orotrakeal yol tercih edilir.

- Özellikle yüz ve boyun yanıklarını içeren ciddi yaralanmalarda, tam obstrüksiyon oluşmadan, yaralanma sonrası ilk 1-2 saat içinde hastanın entübe edilmesi önerilmektedir.
- Boyunda ödem var ise, trakeostomi uygulanmas1nı güçleştireceğinden, bu dönemde trakeostomi uygulanmasından kaçınılır.

- Hasta mekanik ventilatör ile desteklenmelidir. Alveollerin kollabe olmasını ve solunum yetmezliğinin ilerlemesini önlemek için ekspiryum sonu pozitif basınç (PEEP) kullanılabilir.

- Bronkospazm ve hirılt1lı (wheezing) solunumu kontrol etmek üzere bronşların dilatasyonunu sağlayan ilaçlar intravenöz (IV) veya inhale olarak uygulanır.

- Ciddi yanıklı hastalarda arteriyel bir hat kullanılarak AKG'nın sürekli değerlendirilmesi sağlanır. Ayrıca, pulmoner arter basınç kateterleri de pulmoner vasküler direnç (PVD), pulmoner arter basıncı (PAB), pulmoner arter wedge basıncı (PAWB) ve karışık venöz oksijen satürasyonu $\left(\mathrm{SVO}_{2}\right)$ ölçmek için kullanılabilir.

- Hipostatik pnömoniyi önlemek amaciyla her 2 saatte bir hastaya pozisyon verilmelidir.

- İnatçı balgamların tedavisinde mukolitik maddeler kullanılır.

- Hasta şokta değilse ağrı kesici ilaçlar verilir.

- Durumu uygunsa, hastanın saatlik olarak spirometre kullanımı ve her 2 saatte bir derin solunum ve öksürük egzersizleri yapması açısından cesaretlendirilmesi önemlidir (Appleby 2005; Çetinkale 2005; Knipe 2004; Lemon ve Burke 2008; Wraa 2003).

\section{Dolaşımın Sağlanması ve Sürdürülmesi}

Dolaşım ve doku perfüzyonunu değerlendirmek için hastanın her saat yaşam bulgularının, santral venöz basıncının, eğer pulmoner arter kateteri varsa kalp debisinin, pulmoner arter ve pulmoner kapiller wedge basıncının ölçülmesi gerekmektedir. Apikal, karotid ve femoral nabız değerlendirilmeli; cildin rengi ve sıcaklığı kontrol edilmelidir. Eğer hastanın tüm ekstremiteleri yanmışsa, AKB ölçümü zor olabilir. Ödemin artması AKB'nın duyulmasını zorlaştırabilir; Doppler ultrason veya invaziv olmayan elektronik kan basinc1 aleti kullanılabilir (Çetinkale 2005; Nair 2009). 


\section{Sıvı Tedavisi}

Sıv1 tedavisi, kapiller permeabilitenin arttığı acil dönemde dolaşan kan hacminin düzeltilmesini sağlamak amaciyla uygulanır. TBYA \%20'si ve üzeri yanan hastalarda sıv1 tedavisi uygulanır (Mohn-Brown 2008).

Yanık yüzdesine bağlı olarak hastanın kaybettiği sıvı miktarı değişiklik göstereceği için, öncelikli olarak yanık yüzdesi belirlenir. Yanık yüzdesini hesaplamada genellikle, dokuzlar kuralı kullanılmaktadır. Ancak çocuklarda baş ve boyun bölgesi, genellikle tüm vücut yüzeyinin daha büyük bölümüne sahip olduğu için değişik yaş gruplarındaki farklılıklar dikkate alınarak uygulanan Lund ve Browder yöntemi ile daha kesin bir değerlendirme yapılabilir. Yanık yüzdesi hesaplandıktan sonra, sıvı kaybının ciddiyeti ölçüsünde, s1v1-elektrolit dengesinin sağlanması amacıyla hemen yoğun sıvı tedavisine başlanır (Çetinkale 2005; Kanan 2012; Niggemeyer ve Thurman 2012; Stout 2009; Wraa 2003).

Kaybedilen sıvının yerine verilecek olan sıvı miktarını belirleyen çeşitli formüller kullanılabilir. Sıvı tedavisi için yaygın olarak kullanılan Brooke ve Parkland formülleri, hastanın beden ağırlığı ve yanık yüzdesi odaklı hesaplanmalı ve uygulanmalıdır. Parkland formülü, hesaplanması ve hastanın kilosunun izlenmesi kolay olduğu, aynı zamanda sıvı tedavisi için güvenilir bir yöntem sağladığ için yaygın olarak kullanılır (Kanan 2012; Mohn-Brown 2008; Wraa 2003).

\section{Parkland formülü}

4 ml Laktatlı Ringer x Beden Ağırlı̆g 1 (kg) x Total beden yüzey alanının yanık yüzdesi $=$ Yanık sonrası ilk 24 saat için total sıvı gereksinimini belirler.

\section{Uygulama (ilk 24 saat)}

- Total sivinın $1 \frac{1}{2}$ 'si ilk 8 saatte

- Total sıvinın $1 / 4$ 'ü ikinci 8 saatte

- Total sıvının 1/4'ü üçüncü 8 saatte verilir (Eti-Aslan ve Oyur-Çelik 2014; Mohn-Brown 2008; Nail 2009; Niggemeyer ve Thurman 2012).
$\mathrm{Bu}$ formül, sadece bir rehberdir; sıvı tedavisinin, sıv1 hacmine ve hastanın fizyolojik yanıtına göre (bireysel) düzenlenmesi gerektiği unutulmamalıdır (Carrougher ve Sandidge 2009; Çetinkale 2005).

\section{Uygulama (İkinci 24 saat)}

İkinci 24 saatin ilk 8 saatinde plazma miktarı 0.3-0.5 ml x Beden Ağırlığ $1(\mathrm{~kg})$ x Total beden yüzey alanının yanık yüzdesi ile hesaplanır. Hesaplanan miktarın \%20-60'1 uygulanır. Geniş yanıklı hastalarda (TBYA \%30 ve üzeri) idrar çıkışını sağlamak amacıyla Dekstroz $\% 5$ vb. kristalloid solüsyonlar kullanılabilir (Çetinkale 2005; Mohn-Brown 2008).

Hasta bir sağlık kurumuna ulaşır ulaşmaz sıvı tedavisi için, tercihen en az bir ya da iki geniş çaplı (1416 gauge) IV kateter yerleştirilir. Sıvı tedavisi, kristalloid solüsyonlarla (İzotonik Sodyum Klorür, Laktatlı Ringer ya da Dekstroz \%5 vb.), kolloidlerle (Albumin, Dekstran vb.) ya da her ikisinin kombinasyonuyla hekim istemine göre uygulanır (Appleby 2005; Kanan 2012; Knipe 2004; Mohn-Brown 2008; Stout 2009; Wraa 2003).

Sıvı tedavisinin yeterliliği, idrar çıkışı ve hemodinamik izleme dayanır. Kapalı drenaj sistemine bağlı kalıcı üretral kateter, ciddi yanıklı hastalara uygulanacak IV sıv1 tedavisine rehberlik etmek amaciyla saatlik idrar miktarını ölçmek için kullanılmalıdır (Carrougher ve Sandidge 2009; Mohn-Brown 2008; Nail 2009; Stout 2009).

Sıvı tedavisinin yeterliliğini değerlendirme parametreleri; idrar çıkışının yetişkinde $50 \mathrm{ml} / \mathrm{saat}$, elektrik yanığı olan yetişkinde ise $75-100 \mathrm{ml} /$ saat olması, sistolik kan basıncının 90-100 mmHg'dan yüksek, nabız hızının 120/dakika'dan düşük, solunumun ise 16-20/dakika olması ve hastanın kişiye, zamana ve yere oryante olmasidir (Appleby 2005; Kanan 2012; Mohn-Brown 2008).

\section{Yara Bakımı}

Ciddi yanıklı hasta için bakım sonuçları, günlük topikal yara bakımı, yara izleme, yara eksizyonu ve ka- 
patılması yoluyla infeksiyonun önlenmesi ve tedavisine bağlı olarak değişir. Yara bakımının hedefleri şunlardir;

- Mikrobiyal kolonizasyonu kontrol etmek ve yara infeksiyonunu önlemek,

- Yaralanmanın ilerlemesini önlemek,

- Mümkün olduğunca yaranın erken kapanmasını sağlamak,

- Cildin iyileştirme işlevini desteklemektir (MohnBrown 2008; Nail 2009).

Ciddi yanık yarasının bakımında, aseptik koşullar sağlanarak infeksiyon gelişiminin önlenmesi ve yara iyileşmesinin hızlandırılması amacıyla ölü dokuların yara bölgesinden uzaklaştırılması (debridman), tedavi ve bakım girişimlerinde öncelikli uygulamalar arasinda yer alır (Burke ve ark. 2011; Mohn-Brown 2008; Nail 2009).

Yaralanma sonrası yanıklı dokudan salgılanan kimyasal medyatörler, fagositozu başlatmasına karşın nekrotik doku inflamasyon evresini uzatır ve yara iyileşmesini geciktirir. Debridman, yaradan ölü/nekrotik dokularının farklı yöntemler kullanılarak uzaklaştırılması amacıyla yapılan işlemdir. Debridman mekanik, enzimatik ve cerrahi debridman olmak üzere üç şekilde uygulanabilir (Burke ve ark. 2011; Mohn-Brown 2008; Nail 2009).

Mekanik Debridman; gazlı bez ile 1slak-kuru veya sslak-nemli pansuman, hidroterapi, sulama ya da makas kullanılarak kesme, bu kapsamda yer alan debridman yöntemleridir. Ancak, yaraya uygulanan sslak pansuman kuruduğunda çıkarılırken ağrıya neden olabilir ve granülasyon dokusuna zarar verebilir. Hidroterapi sırasında (su dolu bir havuz/küvete daldırma, duşta ya da masada sprey uygulama) skar dokusunu kaldırmak için, yanık yarası nazikçe parfümsüz, antimikrobiyal sabun veya yara temizleyici solüsyon ile yıkanabilir. Çözelti, daha sonra 1lık serum fizyolojik ya da musluk suyu ile durulanır. Yanık yarasının içinde ya da çevresinde 2,5 cm uzaklığa kadar olan tüyler (kaş hariç) tıraş edilmelidir. Soyulmuş cilt, kuru bir gazlı bez ile tutularak yavaşça kaldırılır. Kabarcıklar veya yara kenarları künt makas ile kesilir. Yara, lokal (topikal) bir antimikrobiyal madde kullanılarak kapatılır (Burke ve ark. 2011; Mohn-Brown 2008; Nail 2009).

Enzimatik Debridman; nekrotik doku ile skar dokusunun çözülüp ayrılması için topikal madde kullanılmasını içerir. Enzimatik ajan sadece yara bölgesinde ince bir tabaka olarak uygulanır, ıslak ince gözenekli gazlı bez ile kapatılır ve yara genleşebilen örgü gazlı bez ile sabitlenir. Skar dokusu kalktığında, yara enzimatik maddelerden temizlenir ve granülasyon dokusu gözlemlenir (Burke ve ark. 2011; Mohn-Brown 2008; Nail 2009).

Yara temizliği ve debridman yapıldıktan sonra, açık ya da kapalı yöntem kullanılarak yaranın pansumanı yapılır. Açık yöntemde; hastanın yanık yarasına topikal antibiyotik uygulanır ve pansuman materyali kullanılmaz. Bu yöntem, yaranın kolayca değerlendirilmesini sağlar. Ancak, açık yöntem hipotermi riskini arttırır. Kapalı yöntemde, yara bölgesine antimikrobiyal bir madde kullanılarak yapışmayan bir pansuman materyali ile kapatılır. Yara bölgesi daha sonra yavaşça bir rulo gazlı bez ile sarılır. Kapalı yöntemde genellikle günde iki kez ve gerektiğinde pansuman değiştirilir. Tüm el ve ayak parmakları ayrı ayrı pansuman edilir (Kanan 2012; Knipe 2004; Mohn-Brown 2008; Stout 2009).

\section{Beslenme Desteği}

Ciddi yanıklı hastanın dinlenme durumunda enerji harcaması, katabolizma oluşumu, fiziksel aktivite, yaş ve cinsiyete bağlı olarak, normal değerlerin üzerinde, hatta $\% 100$ oranında artış gösterebilir ve sonuçta toplam kalori gereksinimi 4000 ile 6000 kcal/gün'e kadar yükselebilir. Enerji gereksiniminin artmasının yanık yarasından 1sı kaybına, $\beta$-adrenerjik aktivite artışına, ağrı ve infeksiyona bağl1 geliştiği düşünülmektedir (Burke ve ark. 2011; Mohn-Brown 2008).

Oral alıma dayalı geleneksel beslenme, negatif nitrojen dengesini tersine çevirmede ve iyileşme sürecini başlatmak için gerekli kalori gereksinimlerini karşılamada nadiren yeterli olur. Hipermetabolizmayı den- 
gelemek, nitrojen dengesini iyileştirmek, sepsisi önlemek ve hastanede kalış süresini azaltmak için yaralanmayı takiben 24 ile 48 saat içinde bağırsak sesleri geldiğinde, nazointestinal beslenme tüpü ile enteral beslenme desteklenir. Nazointestinal beslenme tüpü, reflüyü ve aspirasyonu önlemek için pilorun arkasına floroskopi altında yerleştirilir (Burke ve ark. 2011; Kanan 2012; Mohn-Brown 2008; Stout 2009).

Enteral beslenme tercih edilen beslenme yöntemi olmakla birlikte; Curling ülseri, bağırsak tıkanması, beslenme intolerans1, pankreatit veya septik ileus durumunda önerilmemektedir. Enteral yol kullanılamaz olduğunda, subklavian veya juguler ven yoluyla bir santral venöz kateter kullanarak total parenteral beslenme uygulanır (Burke ve ark. 2011; Mohn-Brown 2008; Stout 2009).

TBYA'nın \%10-80'i 2. ve 3. derece yanık olan 103 yetişkin hastada yapılan bir çalışmada; kalori değeri 30 $\mathrm{kcal} / \mathrm{kg} / \mathrm{gün}$ 'den daha az enteral beslenen hastalarda mortalite oranının \%32.6; kalori değeri 30 veya daha fazla $\mathrm{kcal} / \mathrm{kg} / \mathrm{gün}$ ve daha fazla enteral beslenen hastalarda ise mortalite oran $1 \% 5.3$ olduğu ve aralarındaki farkın kalori değeri yüksek beslenen hastalar lehine istatistiksel olarak anlamlı olduğu saptanmıştır. İki grup arasında karşılaştırma yapıldığında; kalori değeri $30 \mathrm{kcal} / \mathrm{kg} /$ gün'den daha az beslenen hastalarda pnömoni sıklığının 2 kat, sepsis riskinin ise 1.8 kat arttığ bulunmuştur (Rimdeika 2006).

\section{Beslenmede Özel Durumlar}

TBYA < \%20 açık yaralar: Sıvı tedavisi uygulanabilir. Beslenme enteral olarak başlatılabilir ve eğer komplikasyon gelişirse parenteral beslenmeye geçilebilir. Yara iyileşme süreci için gerektiği üzere; yüksek kalorili, proteinden zengin besin desteğine odaklanılmalidir (Stout 2009).

$T B Y A \geq \% 20$ açık yaralar: Sıvı tedavisi IV olarak başlatılmalı ve hastanın yanıtına göre tekrar düzenlenmelidir. Belirtildiği gibi kurumun protokolüne uygun olarak; aspirasyon riskini azaltan gastrik tüp ya da küçük çaplı beslenme tüpü ile besin desteğine erken başla- mak gerekir. Yanık yaralanmaları iç organların fonksiyonlarını doğrudan etkilemediği için gastrik tüp ya da küçük çaplı beslenme tüpleri kullanılabilir. Mümkün olduğunca total parenteral beslenmeden (TPN) kaçınilmalidır (Stout 2009).

\section{Destekleyici Girişimler}

\section{Analjezikler ve Sedatifler}

Genellikle dayanılmaz ağriya sebep olan yanığın acil döneminde, etkin ağrı kontrolünü sağlamak için morfin, hidromorfon veya fentanil gibi İV narkotikler kullanılır. Yanık olgusu ve uygulanan tedaviler, hastanın anksiyete düzeyini yükseltebilir ve bağlı olarak midazolam ve lorazepam vb. anksiyolitik maddelerin kullanılması gerekebilir. Anksiyolitikler, özellikle ağrılı bir işlem olan yara bakımından 1 saat önce uygulandığında, etkili olur. Akut dönemde, opioidler dinlenme sırasında ortaya çıkan ağrıyı azaltmak için düzenli olarak uygulanır. Hasta kontrollü analjezi, ağrı ile başa çıkmada hastaya yardımc1 olur (Carrougher ve Sandidge 2009; Eti-Aslan ve Oyur-Çelik 2014; Mohn-Brown 2008).

Acil dönemde, doku perfüzyonunun ve yumuşak doku emiliminin yetersiz olması nedeniyle subkutan (SC) ya da intramüsküler (IM) ilaç uygulamaktan kaçınılır. Oral yol ise gastrointestinal işlev bozukluğu olasıllğ 1 nedeniyle kullanılmaz (Carrougher ve Sandidge 2009; Mohn-Brown 2008).

Hemşirenin, farmakolojik ve farmakolojik olmayan girişimleri birlikte uygulaması ağnı yönetimine olumlu katkı sağlayabilir. Farmakolojik olmayan çeşitli girişimler arasında, yanıklı hastalarda basit, hemen kullanılabilen, öğrenilmesi kolay ve kullanımı sırasında daha az zaman ve çaba gerektiren uygulamaların seçilmesine özen gösterilir. Bu özelliklere uygun olarak basit gevşeme teknikleri; solunum egzersizleri, müzik terapisi, oyalama aktiviteleri vb. farmakolojik olmayan ağrı kontrol yöntemlerine örnek olarak verilebilir (De Jong ve Gamel 2006; Stout 2009).

De Jong, Middelkoop, Faber ve Van Loey (2007)'in yaptığı sistematik derlemede, yanıklı hastaların ağrı 
yönetiminde uygulanan farmakolojik olmayan hemşirelik girişimlerinin incelendiği 17 çalışmadan en çok araştırılan konunun hipnoz olduğu; duyusal odaklanma dışında gevşeme, oyalama ve/veya müzik terapisi vb. yöntemlerin ağrıyı azalttığı belirtilmiştir.

Müzik terapisinin yanıklı hastaların pansuman değişimi sırasındaki ağrı, anksiyete ve kas gerginliği düzeyleri üzerine etkisinin incelendiği bir çalışmada, müzik terapisinin pansuman değişimi öncesi $(p<0.025)$, sıra$\mathrm{s} 1(\mathrm{p}<0.05)$ ve sonras1 $(\mathrm{p}<0.025)$ ağr1 düzeylerinde istatistiksel olarak anlamlı bir azalma olduğu saptanmıştır. Aynı çalışmada, müzik terapisinin pansuman değişimi sırasında anksiyete ve kas gerginliği düzeylerinde $(\mathrm{p}<0.05)$; yanı sıra pansuman değişimi sonrası kas gerginliği düzeyinde $(\mathrm{p}<0.025)$ istatistiksel olarak anlamlı bir azalma olduğu belirlenmiştir (Tan ve ark. 2010).

Burch ve ark. (2012)'nın yanıklı hastalarda terapötik dokunmanın ağrı düzeyi üzerine etkisini değerlendirdiği çalışmasında; terapötik dokunmanın uyguland1ğ1 grupta, hastaneye yatışın 10. gününde ağrıdan kaynaklanan anksiyetenin azaldığı saptanmıştır. Yine aynı grupta 1. ve 2. günde daha az morfin istemi yapıldığ 1 , pansuman öncesi kortizol hormon seviyesinin ise daha yüksek olduğu belirtilmiştir.

\section{Tetanoz Profilaksisi}

Tetanoz toksoidi, anaerobik yara infeksiyonları nedeniyle tüm yanıklı hastalara uygulanır. Hastalara acil dönemin erken aşamasında Clostridium tetani infeksiyonunu önlemek için, yaralanma öncesi 5 yıl içinde tetanoza aktif bağışıklığı olmayan yanıklı hastaların, tetanoz toksoid düzeyleri yükseltilmeli; hiç bağ1şıklı̆g 1 olmayan hastalarda ise tetanoz immünoglobin (pasif bağışıklık ajanı) ve aktif bağışıklık sağlayan tetanus toksoid uygulanmalıdır (Carrougher ve Sandidge 2009; Mohn-Brown 2008).

\section{Antimikrobiyal Ajanlar}

Ciddi yanıklı hastalarda sistemik infeksiyon, yaşam kaybının önde gelen nedenlerinden biridir. Stafilokok ve streptokok gibi gram-pozitif mikroorganiz- malar yanık sonrası ilk hafta yanıklı yüzeye kolonize olur; gram-negatif enterik mikroorganizmalar ise uzun süre hastanede yatmaya bağlı olarak daha yaygın hale gelirler. Kesin infeksiyon tanısı için biyopsi yapılır ve yanık yüzeyinde infeksiyonu ortadan kaldırmak için antimikrobiyal tedavi protokolü uygulanır (Mohn-Brown 2008; Stout 2009).

Antibiyotik ajanlar, yanık yarası temizlendikten sonra topikal olarak uygulanır ve gerekirse üzerine steril gaz örtülür ya da açık bırakılabilir. Yanık yarası florasının kontrolüne ilişkin olan, antibakteriyel tedavide özellikle 48 saatten sonra sistemik antibiyotiklerin kullanılması önerilmez. Bunun nedeni, skar dokusunda kan akımının azalması ya da olmaması antibiyotiklerin yaraya ulaşmasını engeller. Ancak topikal ajanlar skar dokusuna penetre olarak yarada bakteriyel invazyonu yavaşlatır (Eti-Aslan ve Oyur-Çelik 2014; Kanan 2012). Mafenide acetate (Sulfamylon), gümüş nitrat ve silver sulfadiazine (Silvaden) krem en yaygın kullanılan antimikrobiyal ajanlardır. Her üçü geniş spektrumlu antibiyotiklerdir. Lokal antibiyotik seçimi, yanık yarasının genişliğine, tanımlanmış bakteri varlığına, tedavide açık ya da kapalı yöntemin kullanılmas1 ve hastanın yanıtına dayanmaktadır. Antimikrobiyal tedaviye karşın, ciddi yanıklı hasta sepsis ve septik şok gelişimi açısından büyük risk altındadır (Burke ve ark. 2011; Mohn-Brown 2008; Nail 2009; Stout 2009).

Ciddi yanıklı hastalarda genellikle profilaktik olarak antibiyotik uygulanır. Sistemik antimikrobiyal tedavi, eksizyon ve otogreftleme ile ilişkili ameliyat öncesi ve sonrası dönemde hemen uygulanır. Tedaviye hastanın hemodinamik durumu normal değerlere ulaşıncaya kadar (genellikle ameliyat sonrası ilk 24 saat) devam edilir (Mohn-Brown 2008).

\section{Gastrik Hiperasiditenin Önlenmesi}

Hiperasidite, Curling ülserini önlemek amaciyla kontrol altına alınmalıdır. Bakımın acil evresinde, nazogastrik sonda yerleştirilir ve mide içeriği saatlik olarak aspire edilir. Mide içeriğinin pH'1 5 ve üzerinde olmalı ve bu değer korunmalıdır. Gastrik asit salg1lanmasını kontrol etmek için histamin $\mathrm{H}_{2}$ blokerleri 
(famotidine-Pepcid) veya proton pompa inhibitörleri (pantoprazole-Protonix) IV olarak ya aralıklı ya da sürekli infüzyon şeklinde uygulanabilir. Bağırsak sesleri duyulur duyulmaz, antiasit diyete başlanabilir (MohnBrown 2008).

\section{SONUÇ VE ÖNERİLER}

Disiplinler arası bir yaklaşımı gerektiren yanığın acil dönemindeki tedavi ve bakım girişimleri, hastanın yaşamını sürdürmeyi amaçlar. Bu dönemde yapılacak hızlı tanılama, seri, doğru ve zamanında yapılan etkin tedavi ve nitelikli bakım girişimleri, yanıkla ilişkili morbidite ve mortalite oranlarının azaltılması ve hastanın yaşam kalitesinin yükseltilmesinde önemlidir.

Yanıklı hastaya bakım veren hemşire, yanık sonrası oluşan fizyolojik değişikliklere ilişkin güncel ve kapsamlı bilgiye ve hastanın durumundaki ani değişiklikleri fark edebilecek kritik değerlendirme becerisine sahip olmalıdır. Ek olarak hemşire, yanıklı hastayı biyo-psiko-sosyo-kültürel, tüm yönleriyle değerlendirmeli, yaşamsal riski olan hastaya duyarlı, nitelikli bakım sağlayabilmelidir. Hemşire, yoğun stres ve endişe içinde olan yanıklı hasta ve yakınlarıyla olduğu kadar ekip üyeleriyle de etkin iletişim kurabilmeli ve ekip üyeleri arasındaki iletişimin sağlanmasında sorumluluk almalıdır.

\section{KAYNAKLAR}

American Burn Association (ABA) (2006). Guidelines for the operation of burn centers, http://www.ameriburn.org/Chapter14.pdf (06.03.2015).

American Burn Association (ABA) (2013). Burn incidence and treatment in the United States: 2013 Fact sheet, http://www.ameriburn.org/resources_factsheet.php (06.03.2015).

Appleby, T. (2005). Burns. Morton, P. G., Fontaine, D. K., Hudak, C. M., Gallo, B. M. (Eds.). Critical Care Nursing A Holistic Approach. 8th ed., Lippincott Williams \& Wilkins, Philadelphia, 1226-1235.

Burke, K. M., Mohn-Brown, E. L., Eby, L. (2011). Caring for clients with burns. Burke, K. M., Mohn-Brown, E. L., Eby, L. (Eds.). Medical-Surgical Nursing Care. 3th ed., Pearson Education, New Jersey, 1160-1173.
Busch, M. ve ark. (2012). The implementation and evaluation of therapeutic touch in burn patients: An instructive experience of conducting a scientific study within a non-academic nursing setting. Patient Education and Counseling, 89(3): 439-446.

Carrougher, G. J., Sandidge, C. (2009). Management of clients with burn injury. Black, J. M., Hawks, J. H. (Eds.). Medical Surgical Nursing Clinical Management for Positive Outcomes. 8th ed., Saunders, St. Louis, 1239-1269.

Coffee, T. L. (2006). Interventions for clients with burns. Ignatavicius, D. D., Workman, M. L. (Eds.). Medical Surgical Nursing: Critical Thinking For Collaborative Care. 5th ed., Saunders, St. Louis, 1618-1651.

Çetinkale, O. (2005). Yanıklar. Ertekin, C., Taviloğlu, K., Güloğlu, R., Kurtoğlu, M. (Eds.). Travma. İstanbul Medikal Yayıncılık, İstanbul, 563-593.

De Jong, A. E. E., Gamel, C. (2006). Use of a simple relaxation technique in burn care: Literature review. Journal of Advanced Nursing, 54(6): 710-721.

De Jong, A. E. E., Middelkoop, E., Faber, A. W., Van Loey, N. E. E. (2007). Non-pharmacological nursing interventions for procedural pain relief in adults with burns: A systematic literature review. Burns, 33(7): 811-827.

Eti-Aslan, F., Oyur-Çelik, G. (2014). Yanık bakımı. Eti-Aslan, F., Olgun, N. (Eds.). Erişkinlerde Acil Bakım. Akademisyen Tıp Kitabevi, Ankara, 393-413.

Iqbal, T., Saaiq, M., Ali, Z. (2013). Epidemiology and outcome of burns: Early experience at the country's first national burns centre. Burns, 39(2): 358-362.

Kanan, N. (2012). Yanıkta hemşirelik bakımı. Aksoy, G., Kanan, N., Akyolcu, N. (Eds.). Cerrahi Hemşireliği I. Nobel Tıp Kitabevleri, İstanbul, 115-152.

Knipe, C. J. (2004). Burns. Lewis, M. S., Heitkemper, M. M., Dirksen, R. S. (Eds.). Medical Surgical Nursing, Assesment and Management of Clinical Problems. 6th ed., Mosby-Year Book, St. Louis, 515-539.

Kurşun, Ş., Kanan, N. (2011). Yaşlılarda yanığın önlenmesi. TAF Prev Med Bull., 10(2): 251-254.

Mohn-Brown, E. (2008). Nursing care of clients with burns. Lemone, P., Burke, K. (Eds.). Medical Surgical Nursing Critical Thinking in Client Care. 4th ed., Pearson Education, Inc., New Jersey, 487-511.

Nair, U. R. (2009). Emergency and disaster in nursing. Nair, U. R. (Ed.). Textbook of Medical and Surgical Nursing. Jaypee Brothers Medical Publishers, India, 141-160.

Niggemeyer, L., Thurman, P. (2012). Trauma management. Elliott, D., Aitken, L., Chaboyer, W. (Eds.). ACCCN's Critical Care Nursing. 2nd ed., Elsevier, Australia, 644-653. 
Rimdeika, R. (2006). The effectiveness of caloric value of enteral nutrition in patients with major burns. Burns, 32(1): 83-86.

Regojo, P. S. (2008). Management of patients with burn injury. Smeltzer, S. C., Bare, B. G., Hinkle, J. L., Cheever, K. H. (Eds.). Brunner \& Suddarth's Textbook of Medical Surgical Nursing. 11th ed., Lippincott Williams \& Wilkins, Philadelphia, 1994-2039.

Stout, L. R. (2009). Burns. Lynn, D. J., Wiegand, M., Carlson, K. K. (Eds.). Advanced Critical Care Nursing. 1st ed., Saunders, Canada, 1212-1260.
Tan, X., Super, D. M. (2010). The efficacy of music therapy protocols for decreasing pain, anxiety, and muscle tension levels during burn dressing changes: A prospective randomized crossover trial. Journal of Burn Care \& Research, 31(4): 590-597.

Wraa, C. (2003). Burns. Newberry, L. (Ed.). Sheehy's Emergency Nursing Principles and Practice. 5th ed., Mosby-Year Book, St. Louis, 349-362. 